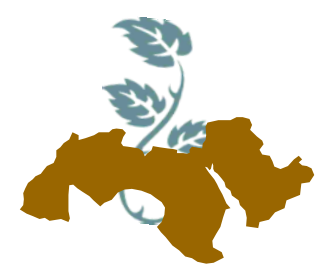

\title{
ORGANIC PEA SPROUT IN DOOR TO IMPROVE PIE QUALITY
}

\author{
Ahmed' E.A.A.S., Nashwa A.I. Abo El-Azam², El-Behairy² U.A.A. \\ and Abdallah ${ }^{2}$ M.M.F. \\ 1- Mediterranean Center for Agriculture Inspection and Certification, Giza, Egypt \\ 2- Horticulture Dept., Fac. of Agric., Ain Shams Univ., P.O. Box 68 Hadayek Shoubra, 11241, \\ Cairo, Egypt
}

Keywords: Pea sprout, vitamins, minerals, pea sprout flour, pies, biological value and nutritional index

\section{ABSTRACT}

Pea sprouts as kind of sprout vegetables, are considered to be more health- beneficial and nutritive. The effect of sprouting pea seeds at open field and laboratory on the green sprouts yield characters and their nutritional values were studied. Result revealed that number of shoots, fresh and dry yield of pea sprout per square meter was increased significantly under laboratory condition over open filed. Protein content was found to increase in green pea sprout at laboratory as compared with open field. Conversely trend was occurred for carbohydrate and lipids. Sprout grown under open filed had the highest content of $\mathrm{P}, \mathrm{K}$, $\mathrm{Ca}, \mathrm{Mg}$ and $\mathrm{Fe}$ compared with laboratory ones. On the other hand, higher vitamin $E$ and $C$ (853.6 and $51.1 \mathrm{mg} / 100 \mathrm{~g}$, respectively) was observed as grown under open filed than laboratory (189.1 and $48.6 \mathrm{mg} / 100 \mathrm{~g}$, respectively). The effect of partial replacement of wheat flour with $12.5 \%$ and $25 \%$ of green and etiolated pea sprout flour on the sensory evaluation and amino acids profile of pea pie were also studied. Supplemented pie with etiolated pea sprout with $12.5 \%$ or $25 \%$ was more preferable by panelists than green sprout flour and nearly to control. The present work confirmed that the recommended supplementation of refined wheat flour should be up to $12.5 \%$ of pea sprout flour. Values of protein efficiency ratio (PER) of pea sprout pies were ranged from 1.06 to 1.69 which higher than control (0.76). The essential amino acid index (EAAI) of pea pie supplemented with $25 \%$ green pea sprouts was useful for food since the value is above $80 \%$. Also, the biological value exhibited the highest value in the same pie. However, highest nutritional index (NI) was obtained from pie supplemented with $25 \%$ green pea sprouts $(23.46 \%)$ over other treatments. Therefore, combination of wheat flour with pea sprout flour can be recommended for high nutritional quality for human, Since it have good protein quality because the amino acid compositions of wheat and peas complement each other, producing a balanced mixture of amino acids.

\section{INTRODUCTION}

Legume seeds are important sources of energy and protein in many parts of the world, both in animal and human nutrition (Kaushik et al 2010). However, their nutritional value may be compromised in part by the presence of undesirable components, known as anti- nutritional factors (ANFs). Peas (Pisum sativum L.), an important food legume, are mainly used for grain production throughout the world. Pea seed contain a moderate amount of high quality protein and a high level of starch, thus making this crop a unique dualpurpose feed, rich in both energy and protein (Cousin, 1997). Germination process has been used for centuries for the purpose of softening the kernel structure, improving its nutritional value, reducing anti-nutritional effects and improving the functionality of seed protein (Kaukovirta-Norja et al 2004 and ljarotimi and Keshinro 2013).

A sprout is one of the most complete nutrition of all foods tested. Sprouts contain vitamins, minerals, proteins and enzymes. The ancient Egyptians and Chinese, thousands of years ago, discovered their nutritional value, while seed germination and production of sprouts is an old habit that 
was adopted thousands of year's age by the ancient (Abdallah, 2008). Sprouts can be considered as an organic food, that they were produced on farms that do not use chemical fertilizers or pesticides, since seed sprouting is the practice of soaking, draining and leaving seeds until they germinate and begin to sprout (Frias et al 1995; Bau et al 1997 and Schulze et al 1997). A diet based on organic products claims to provide health benefits due to the higher concentration of nutritional compounds compared to conventional ones, and the absence of pesticide residues (Oates, 2014). Many searchers study the effect of sprouting on the chemical composition of the seeds or grains. However, there is no study on the yield and seedlings growth under agricultural organic system. In addition, several workers like Saha and Dunkwal, (2009); Tiwari and Awasthi, (2014) and Premakumari et al (2012) etc. have prepared multigrain mixes using cereals, pulses etc. However, limited studies were achieved on the nutritional quality of a combination of grains with sprouted pea flour. Thus, the objectives of this work were:

1. Effect of agricultural organic systems on the yield and nutritional value of sprouted pea seeds.

2. Influence of addition sprouted pea flour on the nutritional value of the pea pie.

\section{MATERIALS AND METHODS}

This study was carried out at winter season of 2015 and 2016 in Horticulture Department, Organic Agriculture Laboratory, Faculty of Agriculture, Ain Shams University, Kaluibia Governorate.

\section{Material}

Organic uniform seeds sizes of pea (Pisum sativum) cultivar Master B were obtained from certified privet farm in Ismailia Governorate, Pea green and etiolated sprouts grown in laboratory. The sprouts were air dried and ground in blender to tiny particles passing through 20 mesh sieve, i.e. similar to the size of wheat flour, wheat flour (72\% extraction), sugar, butter and yeast were obtained from organic local market.

\section{Pea sprouts production}

In a primary experiment green pea sprouts were grown in laboratory compared with open filled using mixed growing medium (45\% vermiculite +
$45 \%$ clay $+10 \%$ compost). Pea seeds were grown at winter season of 2015 and 2016 in plastic trays (7 shelves) in laboratory (1975 g of seeds / $\mathrm{m}^{2}$, while grown in $1 \times 1 \mathrm{~m}$ in the open filed with $10 \mathrm{~cm}$ top layer growing medium recorded before. Selected green sprouts (13 days old) grown in plastic trays in laboratory were used comparing with one day old etiolated pea sprouts grown in glass jar were used for producing sprout flours for pie production.

\section{Processing of Pea sprout pie}

Sprout pie was prepared by partially replacing the wheat flour (72\% extraction) with $12.5 \%$ and $25 \%$ of etiolated or green sprout flour, as compared with $100 \%$ wheat flour, the recipe of the pie was as follow: wheat flour or its mixture with sprout flours $200 \mathrm{~g}$, sugar $16 \mathrm{~g}$, butter $100 \mathrm{~g}$ and yeast $6 \mathrm{~g}$.

Preparation was as follows: the ingredients were mixture together, rounded with adding water as needed for producing pie dough. Dough was punched immediately before panning. Pies were baked in oven at $230^{\circ} \mathrm{C}$ for $15 \mathrm{~min}$ as described before by Hsu et al (1982).

\subsection{Sensory evaluation}

Pea pie samples coded with different numbers were presented to 10 trained panelists, who were asked to rote each sensory attribute by assigning a score of 10 for color, taste, texture and odor as described by Sudha et al (2007).

\subsection{Amino acid and nutritional quality}

Amino acids determination was performed according to AOAC (2012). Nutritional quality of the sprout samples was determined as the amino acid profiles. The essential amino acid index (EAAI) was calculated using the method cited by ljarotimi and Keshinro (2013) according to following equation:

$E A A I=\sqrt[8]{\frac{[\text { Lys } \times \text { Thero } \times \text { Val } \times \text { Meth } \times \text { Isoleu } \times \text { leu } \times \text { Phynyl } \times \text { His }] \text { a }}{[\text { Lys } \times \text { Thero } \times \text { Val } \times \text { Meth } \times \text { Isoleu } \times \text { leu } \times \text { Phynyl } \times \text { His }] b}}$

Where: [lysine, isoleucine, valine, threonine, leucine, phenylalanine, histidine and methionine $]_{a}$ in test sample and [lysine, isoleucine, valine, threonine, leucine, phenylalanine, histidine and methionine $]_{b}$ content of the same amino acids in casein as standard protein (\%) Ibrahim (2017). The nutritional index of the food samples was calculated using the formula below: 
Nutritional index $[\%]=\frac{E A A I \times \% \text { protein }}{100}$

The biological value [BV] was calculated according to Oser (1959) cited by Mune-Mune et al (2011) using the following equation:

\section{$B V($ biological value $)=1.09 \times E A A I-11.7$}

The Protein Efficiency Ratio [PER] was estimated according to the regression equations developed by Alsmeyer et al (1974) as given below: PER (Protein Efficiency Ratio) $=-0.468+0.454$ (LEU)- 0.105(TYR).

Leu/lsolucine ratio was also calculated as shown by Adeyeye (2013).

Amino acid scores (\%) was calculated using the following formula reported by Ibrahim (2017):

Amino acid scores $\%=\frac{\begin{array}{c}\text { Essential amino acids in sprouts } \\ (\mathbf{g} / \mathbf{1 0 0} \mathrm{g} \text { cp })\end{array}}{{ }^{*} \mathrm{cp} \text { : crude protein }} \times 100$

\section{Calculation of other protein quality parameters}

Determination of the ratio of total essential amino acids (TEAA) to the total amino acids (TAA), i.e. (TEAA/TAA), total sulphur amino acids (TSAA), percentage cysteine in TSAA (\% Cys/TSAA), total aromatic amino acids (TArAA), total acidic amino acids (TAAA) and total basic amino acids (TBAA) were estimated from the results obtained for amino acids profiles.

\section{Chemical analysis}

\subsection{Proximate analysis, minerals and vitamin} content

Samples of green pea sprouts produced in laboratory were used for proximate analysis, minerals and vitamin content in comparing with open field sprout samples.

Percentages of moisture, crude protein, ether extract (lipid), crude fiber and ash were determined according to the methods described by AOAC (2012). Total carbohydrate determined by subtracting. The energy value was calculated using the Atwater factor method $[(9 \times$ fat $)+(4 \times$ carbohydrate $)+(4 x$ protein $)]$ as described by Chinma and Igyor (2007) and Nwabueze (2007).
Potassium, magnesium, phosphorus, Calcium and iron determined according to the method described in the AOAC (2012).

Vitamin $\mathrm{E}$ and $\mathrm{C}$ were measured as reported by Leth and Sondergaro (1983).

\section{Statistical analysis}

The data were statistically analyzed by analysis of variance using completely randomized design and least significant difference (L.S.D) at 0.05 levels according to the method described by Snedecor and Cochran (1980).

\section{RESULTS AND DISCUSSION}

\section{Green pea sprouts characters in laboratory versus open field}

Sprouts shoot height and number of leaves didn't significantly affected by open field and laboratory Table 1. While, production under open field (clay soil medium) resulted an increase in sprout shoot weight as compare with laboratory (vermiculite and clay medium "1:1 V:V" in corporate with $10 \%$ compost).

However, under laboratory condition, there are observable increases in number of seedlings and fresh yield of pea per square meter reached $613 \%$ and $174 \%$, respectively over open field. On the other hand, fresh yield per square meter could increase to be $6363 \mathrm{~g}$ as use seven shelves vertically.

In contrary, fresh yield per gram of seeds were increased at open field $(2134 \mathrm{~g})$ over laboratory (460.3g). Seedling dry weight was take similar trend of fresh weight either per square meter or per gram of seeds Table 1.These means that presence of light was improved the growth of shoots in addition to the metabolic changes that take place during the different stages of germination. While the absence of light was resulted an etiolated seedlings which enhanced shoot length at laboratory (indirect sun light) over open field (about 21\% increments). Similar result in the effect of laboratory condition vs. open field on pea shoot characters was obtained by Anwar (2016). Despite everything, pea sprouts grown in laboratory allows obtaining good fresh sprouts all year around compared to open field (in winter only). 
Table 1. Effect of sprouting in the open field vs. laboratory on green pea sprout characters

\begin{tabular}{|c|c|c|c|}
\hline Characters & $\begin{array}{l}\text { Open } \\
\text { field }\end{array}$ & Laboratory & $\begin{array}{l}\text { LSD } \\
(0.05)\end{array}$ \\
\hline $\begin{array}{l}\text { Sprout shoots length } \\
\text { (cm) }\end{array}$ & 7.62 & 9.22 & N.S \\
\hline No. of leaves / sprout & 3.13 & 3.00 & N.S \\
\hline $\begin{array}{l}\text { Sprout shoot fresh } \\
\text { weight }(\mathrm{mg})\end{array}$ & 551 & 211 & 400.7 \\
\hline $\begin{array}{l}\text { Sprout shoot dry } \\
\text { weight }(\mathrm{mg})\end{array}$ & 54.3 & 20.2 & 94.3 \\
\hline No. of shoots $/ \mathrm{m}^{2}$ & 603 & $30109+$ & 1303.9 \\
\hline $\begin{array}{l}\text { Fresh yield of shoots } \\
\left(\mathrm{g} / \mathrm{m}^{2}\right)\end{array}$ & 332.3 & $6363+$ & 400.7 \\
\hline $\begin{array}{l}\text { Fresh yield of shoots } \\
\text { ( } \mathrm{g} / \mathrm{kg} \text { of seeds) }\end{array}$ & 2134 & 460.3 & 14.2 \\
\hline $\begin{array}{l}\text { Dry weight of shoots } \\
\left(\mathrm{g} / \mathrm{m}^{2}\right)\end{array}$ & 32.73 & $608.8+$ & 94.3 \\
\hline $\begin{array}{l}\text { Dry weight of shoots } \\
\text { (g/kg of seeds) }\end{array}$ & 210.2 & 44.04 & 29.8 \\
\hline
\end{tabular}

$+=7$ shelves $=7 \mathrm{~m} 2, \mathrm{~N} . \mathrm{S}=$ not significant, LSD $=$ Least Significant Difference Test.

2. Effect of sprouting in the open field vs. laboratory on the proximate analysis, mineral and vitamin of green pea sprout

Green pea sprouts were grown under two growth conditions, open field and laboratory using the same vermiculite and clay medium (1:1 v:v) incorporated with $10 \%$ compost. The proximate analysis, minerals and vitamin content are shown in Table 2. The results showed that there was about $24.1 \%$ reduction in moisture in sprouting under open field conditions compared with laboratory environmental conditions.

Protein content was found to increase about $19.2 \%$ in green pea sprouts grown at laboratory as compared with open field condition (on a dry weight basis).

These results may be due to the lower shoot dry weight in sprouts grown in laboratory $(20.2 \mathrm{mg})$ compared with open field shoot dry weight (54.3 $\mathrm{mg}$ ). Similar result was obtained by Anwar (2016). Regarding to lipid content; growing sprouts under open field brought high lipid content $(4.65 \%)$ over laboratory $(2.75 \%)$ Table 2. Similar trend was observed for carbohydrate content and these results may be because that during germination the reserve of carbohydrates especially in legume seeds consumed as energy source to start germination and various processes occurring in the seeds. Moreover, in open field, as direct sunlight is available the young seedling can photosynthesize causing an increase in carbohydrate content in compare with indirect sunlight at laboratory condition.

Table 2. Proximate analysis, minerals and vitamins content of green pea sprout shoots grown in open field and laboratory.

\begin{tabular}{|c|c|c|}
\hline Nutrients & Open field & Laboratory \\
\hline Moisture \% & $8.57 \mathrm{~b}$ & $11.29 \mathrm{a}$ \\
Protein \% & $44.3 \mathrm{~b}$ & $52.8 \mathrm{a}$ \\
Lipids \% & $4.65 \mathrm{a}$ & $2.75 \mathrm{~b}$ \\
Carbohydrates \% & $23.9 \mathrm{a}$ & $16.2 \mathrm{~b}$ \\
Fiber \% & $8.37 \mathrm{~b}$ & $8.74 \mathrm{a}$ \\
Ash \% & $10.21 \mathrm{a}$ & $8.22 \mathrm{~b}$ \\
Energy Kcal. & $314.7 \mathrm{a}$ & $300.8 \mathrm{~b}$ \\
\hline \multicolumn{3}{|c|}{ Minerals ( $\mathrm{mg} / \mathbf{1 0 0 g})$} \\
\hline P & $820 \mathrm{a}$ & $750 \mathrm{~b}$ \\
K & $3480 \mathrm{a}$ & $2760 \mathrm{~b}$ \\
Ca & $224 \mathrm{a}$ & $79 \mathrm{~b}$ \\
Mg & $300 \mathrm{a}$ & $160 \mathrm{~b}$ \\
Fe & $6.42 \mathrm{a}$ & $4.98 \mathrm{~b}$ \\
\hline \multicolumn{3}{|c|}{ Vitamins (mg/100g) } \\
\hline Vit. E & $853.59 \mathrm{a}$ & $189.12 \mathrm{~b}$ \\
Vit. C & $51.12 \mathrm{a}$ & $48.57 \mathrm{~b}$ \\
\hline
\end{tabular}

Means in each raw followed by the same letter are not significantly different at the $5 \%$ level.

Highest fiber content was recorded at laboratory condition. Growing sprouts under open field condition caused an increase in ash content in compare with laboratory condition. However, Santos et al (2014) showed that pea leaves had a high water $(91.5 \%)$ and low fat $(0.3 \%)$ and carbohydrate $(1.9 \%)$ contents, being a good source of dietary fiber $(2.1 \%)$ compared to other ready-to-eat green leafy vegetables.

As estimated the energy value of pea sprouts shoot, it would be $314.7 \mathrm{Kcal}$ for open field while it was $300.8 \mathrm{Kcal}$ for laboratory. Thus, pea sprouts can provide human body with different nutrients with low calorie. Pèrez-Balibrea et al (2008) reported that pea seedling, as kind of green sprout vegetable, is considered to be more healthbeneficial and nutritive. Although, pea seedling has only ten or dozens of days for growth, light environment is an important and adjustable factor 
which has potential in regulating yield and nutritional quality. It can be concluded that open field cause an improvement in the nutrition value of pea sprouts; however, produce sprouts under laboratory enhance its protein content with low fiber content and this may be preferable for many consumers.

Table 2 also presents the elements content of green pea sprouts grown under two sprouting conditions. Sprouts grown in the open field had the highest content of phosphorus, potassium, calcium, magnesium, and iron (on dry weight basis) compare with laboratory condition. The increment in elements content in the open filed condition may be related to the presence of light during the sprouting process and the absorption of elements from open field growing medium as reported before by Anwar (2016). However Santos et al (2014) reported that pea shoots showed a high content of potassium and phosphorous compared to other ready-to-eat green leafy vegetables.

Also, Ahmed (2014) showed that the content of $\mathrm{K}$ of turnip and radish sprouts increased under open field conditions with clay + vermiculate $(1: 1$ $\mathrm{v} / \mathrm{v})+10 \%$ compost $(8640$ and $9310 \mathrm{mg} / 100 \mathrm{~g}$, as dry weight respectively). The obtained results confirmed that minerals content were affected by growing media and environment. Although, vermiculite with clay medium was used at laboratory and open field, sprouts under open field condition contain $183 \%$ of $\mathrm{Ca}$ and $87.5 \%$ of $\mathrm{Mg}$ more than content under laboratory condition.

Green pea sprouts grown in the open field contained higher vitamin $E$ and $C$ than those of laboratory grown sprouts Table 2 . These results may be due to the presense of direct light under open field condition. Usage mixed growing medium (verm. + clay $+10 \%$ compost) in the open field enhanced sprout's content of vitamin $\mathrm{E}$ and $\mathrm{C}$.

The results tend to open field condition is more suitable for produce green pea sprouts with high content of vitamin $E$ and $C$, especially with using verm. + clay $+10 \%$ compost medium .

During sprouting (germination) several enzyme systems become active and bring about profound changes in the nutritive value of pulses. Vitamin C, which was practically absent in dry legume seeds, increased in amounts after sprouting (Pallanca and Smirnoff (1999) and Shah et al (2011). However, Santos et al (2014) reported that pea shoots showed a high content of vitamins $C, E$ and $A$ compared to other ready-to-eat green leafy vegetables.

\section{Sensory evaluation of pie supplemented with pea sprouts flour}

The average results for the pie taste of the market flour (control) and supplemented peas sprout flour are shown in Table 3 . The maximum mean taste and color value were observed in $\mathrm{T}_{3}$ (12.5\% ESF : $87.5 \%$ WF) with no significant different than control pie while the minimum mean value were recorded in $\mathrm{T}_{4}$ (25\% GSF : $\left.75 \% \mathrm{WF}\right)$. Statistical analysis showed that supplementation had significantly influenced taste and color of the pies. Results exhibited a decrease in the quality of green pea sprouts flour $12.5 \%$ and $25 \%$ supplemented pies followed by $25 \%$ of etiolated pea sprouts flour supplemented pies in terms of taste and color.

Table 3. Sensory evaluation of pea pie as affected by replacement of wheat flour with $12.5 \%$ and $25 \%$ of etiolated and green sprouted pea seed flour

\begin{tabular}{|c|c|c|c|c|}
\hline Supplementation levels & Taste & color & texture & Odor \\
\hline$\left(\right.$ Control ,WF) $\mathrm{T}_{1}$ & $8.4 \mathrm{ab}$ & $8.9 \mathrm{a}$ & $9.0 \mathrm{a}$ & $9.2 \mathrm{a}$ \\
\hline (12.5\% GSF : $87.5 \%$ WF) $\mathrm{T}_{2}$ & $6.5 \mathrm{c}$ & $6.5 \mathrm{c}$ & $8.0 \mathrm{bc}$ & $6.5 \mathrm{~b}$ \\
\hline$\left(12.5 \%\right.$ ESF : $87.5 \%$ WF $\mathrm{T}_{3}$ & $8.9 \mathrm{a}$ & $8.8 \mathrm{a}$ & $8.4 \mathrm{ab}$ & $9.0 \mathrm{a}$ \\
\hline (25\% GSF : $75 \%$ WF) $\mathrm{T}_{4}$ & $5.7 \mathrm{~d}$ & $6.0 \mathrm{c}$ & $7.4 \mathrm{c}$ & $5.8 \mathrm{~b}$ \\
\hline$(25 \%$ ESF : $75 \%$ WF $) \mathrm{T}_{5}$ & $7.9 \mathrm{~b}$ & $7.8 \mathrm{~b}$ & $8.1 \mathrm{bc}$ & $8.6 \mathrm{a}$ \\
\hline $\operatorname{LSD}(<0.05)$ & 0.64 & 0.63 & 0.70 & 0.80 \\
\hline
\end{tabular}

WF: wheat flour, GSF: green pea sprouts flour and ESF: etiolated pea sprouts flour

Means in each raw followed by the same letter are not significantly different at the $5 \%$ level.

The decrease may be attributed to the dry leafy greens flavor of green pea sprouts flour; however, supplemented with etiolated pea sprouts flour provide pies with beany or nuts flavor. Similarly, the maximum mean values (8.9 and 8.8 ) were noted in $\mathrm{T}_{1}$ (Control, WF) and $\mathrm{T}_{3}(12.5 \% \mathrm{ESF}: 87.5 \% \mathrm{WF})$, whereas the minimum mean value (6.0) was found in $\mathrm{T}_{4}(25 \%$ GSF : $75 \% \mathrm{WF})$. The dark color dominated with the gradual increase in green pea sprouts flour.

The average results for the texture of the control and supplemented pies also are shown in Table 3. Statistical analysis revealed that the texture score of the pies had significantly decreased with the progressive increase in pea sprouts supplementation especially in green sprout flour and the 
high value (9.0) was recorded in $T_{1}$ (control) followed by $T_{3}$. The decrease may be due to the increase in fiber content of pea sprout flour blend. Maximum mean value of odor was observed in $T_{1}$ followed by $\mathrm{T}_{3}(12.5 \%$ ESF: $87.5 \% \mathrm{WF})$ and $\mathrm{T}_{5}$ (25\% ESF : $75 \%$ WF), which were not significantly differed Table 3. Pomernaz et al (1977) reported that bread supplemented with $10 \%$ flour from germinated soyabean resulted in highly satisfactory bread quality. While, Finney (1977) showed that replacing $7 \%$ wheat flour with wet, mashed and germinated soyabean produced bread with no objectionable taste or odor. Finney et al (1980) replaced $15 \%$ of wheat flour with germinated, un germinated and dehulled faba bean, they produced acceptable breads using both the suger and sugarfree formulas. However, Hsu et al (1980) reported that germination adversely affected baking properties of yellow peas and lentils but not faba bean. The adverse effect of germination on baking properties of legume flours is partly due to changes in starch (Morad et al 1980). Abdallah and Abo ElNaga (2013) reported that using unsieved sprouted whole wheat grain flour and dehulled sprouted faba bean seed flour with sprouted naked barley flour for cake production, showed that there are no significant difference between control treatments and $100 \%$ or $50 \%$ sprouted whole wheat grain flour substitution treatments for sensory attributes crust color and crumb appearance. Moreover, Abdallah et al (2017) reported that the replacements of wheat flour by seeds sprout flours at different levels could improve nutritional quality, physical characteristics and sensory characteristics of produce cupcakes especially when using of sprouted faba beans and chickpea flour. Also, Ibrahim (2017) recorded that the best biscuit samples were prepared from sprouted wheat supplement with $50 \%$ sprouted chickpea flour which recorded the highest panel test (7.9) and color (8.1) but it occupied the third texture test (8) after soft (8.8) and coarse (8.3) market flour biscuits.

Overall; supplemented pies with white (etiolated) pea sprout either with $12.5 \%$ or $25 \%$ was more preferable by panelists and nearly to control. The presents work confirmed that the recommended supplementation of refined wheat flour should be up to $12.5 \%$ of green pea sprouts flour and up to $25 \%$ of etiolated sprouts flour, which could produce acceptable pies with high nutritional quality.
4. Effect of supplemented wheat flour with pea sprouts flour on the amino acids profile and nutritional quality of pea pie

The incorporation of ingredients like legume flour, concentrate or isolate in cereal-based matrices can lead to the production of nutritionally enhanced products like bread with high protein content. Many studies have been made on the supplementation of wheat flour with legume based ingredients like lupin flour (Paraskevopoulou et al 2010), pea flour (Morad et al 1980), faba bean flour or concentrate (Abdallah and Abo El-Naga, 2013 and Abdallah et al 2017), chickpea flour (Abdallah et al 2017 and Ibrahim, 2017) and soy protein flour or isolate (Khan and Lawhon, 1980) to produce enriched bread and bakery products. Substitution with legume-based products allows to improve bread protein content and to compensate wheat deficiencies in lysine and threonine, two essential amino acids (Kies and Fox, 1970 and Pollard et al 2002). Amino acids content and nutritional quality of pies supplemented with $12.5 \%$ of green and etiolated pea sprouts flour ( $\mathrm{T}_{2}$ " $12.5 \%$ GSF: $87.5 \%$ WF" and $\mathrm{T}_{3}$ "12.5\% ESF: $87.5 \%$ WF") and $25 \%$ of green and white pea sprouts flour $\left(\mathrm{T}_{4}\right.$ "25\% GSF: $75 \%$ WF" and $T_{5}$ " $25 \%$ ESF: $75 \%$ WF") as compare with $100 \%$ wheat flour $\left(\mathrm{T}_{1}\right.$, control) are presented in Table 4. Data showed that glutamic acid was found to be the most abundant in $T_{4}$ (23.44 g/100g cp.) followed by $\mathrm{T}_{2}(19.94 \mathrm{~g} / 100 \mathrm{~g}$ cp.), $T_{5}$ (18.02 g/100g cp.) and $T_{3}(15.33 \mathrm{~g} / 100 \mathrm{~g}$ $\mathrm{cp}$.) while $T_{1}$ control $(11.74 \mathrm{~g} / 100 \mathrm{~g} \mathrm{cp}$.) was the lowest. Similar results were reported by Roohinejad et al (2009), Moongngarm and Saetung (2010) and ljarotimi (2012). However, Bak et al (2006) found that decarboxylation of glutamic acid increased Gama Amino Buteric acid (GABA) synthesis, as of the most interesting compounds in germinated cereal grains which plays a vital role in central nervous system, as inhibitory neurotransmitter and it has hypotensive effect on blood pressure (Xu and Godber, 2001). On the other hand, methionine was the least in all treatments (ranged from $0.84 \mathrm{~g} / 100 \mathrm{~g}$ in $\mathrm{T}_{1}$ to $1.32 \mathrm{~g} / 100 \mathrm{~g}$ in $\mathrm{T}_{4}$ ). Also, limited amino acid cysteine was found in all treatment which ranged from $0.90 \mathrm{~g} / 100 \mathrm{~g}$ in $T_{1}$ to 3.74 $\mathrm{g} / 100 \mathrm{~g}$ in $\mathrm{T}_{4}$. Generally, sprouting caused an increase in the content of almost amino acids especially in pie prepared from green pea sprout flour except arginine and aspartic acid and this results were in agreement with Shu et al (2008) and Moongngarm and Saetung (2010), they found about similar results. 
Table 4. Amino acid profile and nutritional quality of pea sprouts pie

\begin{tabular}{|c|c|c|c|c|c|c|}
\hline & & $\mathrm{T}_{1}$ & $\mathbf{T}_{2}$ & $\mathbf{T}_{3}$ & $\mathbf{T}_{4}$ & $T_{5}^{(1)}$ \\
\hline & Casein standard & \multicolumn{5}{|c|}{ Essential amino acids (g/100g cp.) } \\
\hline Theronine & 3.78 & 1.73 & 1.84 & 2.14 & 1.87 & 2.16 \\
\hline Valine & 5.82 & 3.05 & 3.85 & 3.29 & 4.53 & 3.87 \\
\hline Isoleucine & 4.54 & 1.67 & 2.5 & 2.14 & 2.90 & 2.48 \\
\hline Leucine & 8.28 & 3.29 & 4.72 & 3.90 & 5.53 & 4.56 \\
\hline Phenylalanine & 4.55 & 2.81 & 3.36 & 2.69 & 4.15 & 3.31 \\
\hline Histidine & 2.55 & 1.31 & 1.57 & 1.20 & 1.92 & 1.47 \\
\hline Lysine & 7.09 & 1.73 & 1.41 & 1.75 & 1.59 & 1.98 \\
\hline Methionine & 2.57 & 0.84 & 1.25 & 1.04 & 1.32 & 1.11 \\
\hline Total (EAA) & 39.18 & 16.46 & 20.54 & 18.19 & 23.82 & 20.97 \\
\hline \multicolumn{7}{|c|}{ Conditionally essential amino acids (g/100g cp.) } \\
\hline Tyrosine & & 2.51 & 2.93 & 2.36 & 3.32 & 2.67 \\
\hline Arginine & & 3.05 & 2.11 & 2.36 & 2.44 & 2.71 \\
\hline Cysteine & & 0.90 & 2.17 & 0.98 & 3.75 & 1.70 \\
\hline Proline & & 2.15 & 6.84 & 3.90 & 8.41 & 4.79 \\
\hline Glycine & & 1.97 & 2.66 & 2.14 & 3.32 & 2.67 \\
\hline \multicolumn{7}{|c|}{ Non-essential amino acids (g/100g cp.) } \\
\hline Aspartic acid & & 11.91 & 3.42 & 4.12 & 3.87 & 4.65 \\
\hline Serine & & 2.03 & 2.55 & 2.91 & 2.55 & 2.90 \\
\hline Gluctamic acid & & 11.74 & 19.95 & 15.33 & 23.44 & 18.02 \\
\hline Alanine & & 2.51 & 3.04 & 2.41 & 3.94 & 3.13 \\
\hline Total ( NEAA) & & 38.80 & 45.70 & 36.53 & 55.04 & 43.27 \\
\hline Total amino acids & & 55.26 & 66.25 & 54.72 & 78.87 & 64.23 \\
\hline \multicolumn{2}{|c|}{ Parameters } & \multicolumn{4}{|c|}{ Nutritional quality ${ }^{(2)}$} & \\
\hline TEAA/TAA \% & & 29.79 & 31.00 & 33.23 & 30.21 & 32.63 \\
\hline TNEAA/TAA $\%$ & & 70.20 & 68.99 & 66.76 & 69.79 & 67.36 \\
\hline TEAA/TNEAA & & 0.42 & 0.44 & 0.49 & 0.43 & 0.48 \\
\hline TSAA( Meth. + Cys ) & & 1.73 & 3.42 & 2.03 & 5.07 & 2.81 \\
\hline Cys / TSAA \% & & 51.72 & 63.49 & 48.64 & 73.89 & 60.65 \\
\hline TArAA ( Pheny + Tyr) & & 5.30 & 6.30 & 5.05 & 7.47 & 5.99 \\
\hline Leu / Isoleu & & 1.96 & 1.89 & 1.82 & 1.90 & 1.83 \\
\hline TAAA ( Asp + Glu) & & 23.65 & 23.36 & 19.45 & 27.31 & 22.67 \\
\hline Asp/Glu & & 1.01 & 0.17 & 0.26 & 0.16 & 0.25 \\
\hline TBAA ( Arg + Lys) & & 4.79 & 3.53 & 4.12 & 4.03 & 4.70 \\
\hline TEAA+Arg+His/TAA \% & & 37.70 & 36.58 & 39.75 & 35.74 & 39.16 \\
\hline PER & & 0.76 & 1.37 & 1.06 & 1.69 & 1.32 \\
\hline EAAI \% & & 86.02 & 84.90 & 87.70 & 84.1 & 87.1 \\
\hline BV \% & & 82.06 & 80.84 & 83.89 & 79.96 & 83.20 \\
\hline Nutritional index $\%$ & & 14.37 & 15.45 & 16.14 & 23.46 & 18.89 \\
\hline
\end{tabular}

(1) $T_{1}=100 \%$ wheat flour (control), $T_{2}=12.5 \%$ green pea sprout flour, $T_{3}=12.5 \%$ etiolated pea sprouts flour, $T_{4}=25 \%$ green pea sprout flour and $T_{5}=25 \%$ etiolated pea sprouts flour

(2) $T E A A=$ total essential amino acids, TAA=total amino acids, TNEAA=total non-essential amino acids, TSAA=total sulphur amino acids, TArAA=total aromatic amino acids, TAAA=total acidic amino acids, TBAA= total basic amino acids, $\mathrm{PER}=$ Protein Efficiency Ratio, EAAI =essential amino acid index, $\mathrm{BV}=$ biological value. 
The results of protein quality of sprouted pea pie were also presented in Table 4. The percentage of total essential amino acids showed that $T_{4}$ had the highest value compared with $T_{1}$ control. The total aromatic amino acids (TArAA) of pea sprouts pie were ranged from 5.05 to $7.47 \mathrm{~g} / 100 \mathrm{~g}$ $\mathrm{cp}$. Pea sprouts pie at all treatments showed higher percentage ratio of total essential amino acid (TEAA) to the total amino acids (TAA) (from $30.21 \%$ to $33.23 \%$ ) as compared with control pie $(29.79 \%)$. These values were close to the value of $39 \%$ considered adequate for ideal protein food for infants and above the $26 \%$ for ideal protein food for children and $11 \%$ for adult (FAO/WHO/UNU, 1985). Total acidic amino acid (TAAA) ranged from $19.45 \%$ to $27.31 \%$ in sprout and control pies, which was higher than total essential amino acid (TEAA) whilst, the percentage range in total basic amino acid (TBAA) from 3.53 to $4.79 \%$ that made them the third largest group among the pea pie samples.

An observation in Asp/Glu showed that the highest level was found in $T_{1}$ relative to the other treatments. While Leu/lleu ratio was almost similar in pea pie sample (especially $\mathrm{T}_{4}$ ) compared with control $\left(T_{1}\right)$. Most of pie samples contain more Cys than Meth. for examples Cys/TSAA percentage was $73.9 \%$ for $T_{4}$ compared with control $\left(T_{1}\right)$ which recorded 51.7\% Table 4. Adeyey, (2004) reported that many vegetables proteins contains substantially more Cys than Meth. In contrast animal proteins are low in Cys (Adeyeye and Ayejuyo, 2007). However the present pea sprout pie sample results Cys/TSAA. Cys has positive effects on mineral absorption particularly zinc (Sandstrom et al 1989 and Mendozd, 2002).

The most widely used method for measurement of protein quality is protein efficiency ratio (PER) test, which is the weight gained by the rats (biological assays) divided by the weight of protein consumed. Nowadays, Alsmeyer et al (1974) equations using amino acid (AA) practical and less expenses and time required for the assay test. The values of protein efficiency ratio (PER) of the pea pie samples were between 0.76 in $T_{1}$ (control) to 1.69 in $\mathrm{T}_{4}$ (25\% GSF: 75\% WF). However, the protein efficiency ratio (PER) in pea sprout pies were less than 2.5 which found in reference casein (Oyarekua and Eleyinmi, 2004), but they were variably compared to millet ogi (1.62) (Oyarekua and Eleyinmi, 2004).

Protein quality can also be measured using biological value (BV) and essential amino acid in$\operatorname{dex}(E A A I)$. The essential amino acid index EAAI of $\mathrm{T}_{3}$ and $\mathrm{T}_{5}$ had the highest value (about 87.7 and $87.1 \%$ ) over other treatments. The essential amino acid index EAAl of all treatment was useful for food since the values are above $70 \%$. Oser (1959) reported that protein based food is in adequate when it's EAAI below $70 \%$ and useful since EAAI value is around $80 \%$.

Scientifically, it is well known that a proteinbased food nutritional is a good nutritional quality when its biological values (BV) are high $(70 \%$ to $100 \%)$ (Oser, 1959). BV exhibited the highest value in $\mathrm{T}_{3}(83.9 \%)$ followed by $\mathrm{T}_{5}(83.2 \%)$ and $\mathrm{T}_{4}$ was the lowest (79.9\%). Data in Table 4. showed that $\mathrm{T}_{1}$ recorded the lowest nutritional index $\mathrm{NI}$ $(9.86 \%)$.

In contrast, the highest $\mathrm{NI}$ was obtained in $\mathrm{T}_{4}$ $(23.46 \%)$. Wheat is a low in some essential amino acids, notably lysine. Therefore, the traditional wheat-based food product, e.g biscuits are generally of poor nutritional quality for human and this could have been the reason for the high prevalence of the protein malnutrition among weaning aged children in developing countries, where cereals are solely used as complementary foods (Okoye, 1992 and Devlin, 1997).

\section{Amino acids score}

Essential amino acid score expressed as percentage of the content of each essential amino acid in the sample protein to the same essential amino acid in the same quantity of a protein selected as a standard (Casein). The essential amino acid showing the lowest percentage in called (first limiting amino acid) in the test sample protein. The true limiting amino acid in the protein is, however, the amino acid limiting growth in biological experiment. Data in Table 5. showed that the first limiting amino acid score was Lysine (19.9 to $27.9 \%$ ) in all treatments, followed by Methionine (32.6 to $51.5 \%$ ).

Finally sprouting pea seeds in simple language tills human how to become a mini organic gardener in his own home.

\section{REFERENCE}

Abdallah, M.M.F. 2008. Seed sprouts, a pharaoh's heritage to improve food quality. Arab Univ. J. of Agric. Sci. 16(2), 469-478.

Abdallah, M.M.F. and Abo El-Naga, M. 2013. Use of seed sprouts flour to improve cake quality. J. of Biolo. Chem. and Environ. Sci. 8(1), 279298. 
Abdallah, M.M.F.; Ghanem, Kh. M.; Abo ElNaga, M. M.; El-Sheshtawy, A. A. and Abd El-Gany, T. S. A. 2017. Effect of wheat flour supplemented with some seed sprouts flours on cake qualities. J. of Biolo. Chem. and Environ. Sci. 12(3), 113-130.

Adeyeye, E.I. 2004. The chemical composition of liquid and solid endosperm of ripe coconut. Oriental J. of Chem., 20 (3), 471-476.

Adeyeye, E.I. 2013. The comparison of the amino acids profiles of whole eggs of duck, francolin and turkey consumed in Nigeria. Global. J. Sci. Fron. Res. Vol. XIII Ver.1, 10-20.

Adeyeye, E.I. and Ayejuyo, O.O. 2007. Proximate, amino acid and mineral composition of turkey henmuscle and skin. Orient. J. Chem., 23(3), 879-886.

Ahmed, M.Y. 2014. Effect of germination methods on sprout production and active ingredient contents of some cruciferous crops. M.Sc. Thesis of Fac. Agric. Ain Shams Univ., Cairo, Egypt, pp. 37-51.

Alsmeyer, R.H., Cunningham, A.E. and Happich, M.L. 1974. Equations predict PER from amino acid analysis. Food Technology. 7(28), 34-40.

Anwar, Dina. A. 2016. Effect of number of harvests on the production and nutritive value of mushroom fruits, sprout vegetables and their residues. Ph.D. Thesis of Fac. Agric. Ain Shams Univ., Cairo, Egypt, pp. 93-106.

AOAC. 2012. Official Methods of Analysis of AOAC International.19 ${ }^{\text {th }}$ ed. Dumes Method.No. 968.06. Chapter 4, pp. 9-56.

Bak, L., Schousboe, A.K. and Waagepetersen, H.S. 2006. The glutamate/ GABA glutamine cycle: aspects of transport neurotransmitter homestasis and ammonia transfer. J. Food Sci. Technol. Intr, 11(1), 33-40.

Bau, H., Villaume, C., Nicolas, J. and Mejean, L. 1997. Effect of germination on lysine inhibiter activity in lentil and pigeon pea. J. Food Sci. Tech. 23, 260-263.

Chinma, C.E. and Igyor, M.A. 2007. Micronutrients and anti-nutritional contents of selected tropical vegetable grown in South East. Nigeria. Nig. Food J. 25, 111-116.

Cousin, R. 1997. Peas (Pisum sativum L.). Field Crop Res. 53, 111-130.

Devlin, M.T. 1997. Textbook of biochemistry with clincal correlations. $4^{\text {th }}$ ed. Wiley-Liss Inc. New York, USA, pp. 540-548.
FAO/WHO/UNU, 1985. Energy and protein requirements. WHO Technical Report Series No. 724. Geneva, pp. 1-206.

Finney, P.L. 1977. A review of older and some newer short-time bread baking studies. Bakers Dig. 51(5), 81-86.

Finney, P.L., Morad, M.M. and Hubbard, J.D. 1980. Germinated and un germinated faba bean in conventional U.S. breads made with and without sugar and in Egyptian balady breads. Cereal Chem. 54 (4), 267 - 270.

Frias, J., Diaz-Pollan, C., Hedley, C.L. and VidalValverde, C. 1995. Evaluation of trypsin inhibitor activity during germination of lentils $\mathbf{J}$. Agric. Food Chem., 43, 2231- 2234.

Hsu, D., Leung, H.K., Finney, P.L. and Morad, M.M. 1980. Effect of germination and nutritive value and baking properties of dry peas, lentils and faba beans. J. Food Sci. 45, 87-92.

Hsu, D., Leung, H.K., Finney, P.L. and Morad, M.M. Finney, P.L. and Leung, C.T. 1982. Effect of germination on electrophoretic, functional and bread-baking properties of yellow Pea, lentil and faba bean protein isolates. Cereal Chem. 59(5), 344-350.

Ibrahim, E.M.R. 2017. Effect of sprouting using saline water on characters and chemical composition of some legumes and cereals seeds. Ph.D. Thesis, Fac. Agric. Ain shams Univ., Cairo, Egypt, pp. 32-80.

ljarotimi, O.S. 2012. Influence of germination and fermentation on chemical composition, protein quality and physical properties of wheat flour (Triticum aestivum). J. Cereals and Oil Seeds. 3(3), 35-47.

ljarotimi, S.O. and Keshinro, O.O. 2013. Determination of nutrient composition and protein quality of potential complementary foods formulated from the combination of fermented popcorn, African locust and Bambara groundnut seed flour. Polish J. Food Nutr. Sci. 63(3), 155-166.

Kaukovirta-Norja, A., Wilhemson, A. and Poutanen, K. 2004. Germination: A means to improve the functionality of oat. Agric. Food Sci. 13, 100-112.

Kaushik, G., Satyaand, S. and Naik, S.N. 2010. Effect of domestic processing techniques on the nutritional quality of soybean. Mediterr. J. Nutr. Metab. 3, 39-46.

Khan, M.N. and Lawhon, J.T. 1980. Baking properties of oilseed protein and isolates produced with industrial membrane systems. Cereal Chem. 57, 433-436. 
Kies, C. and Fox, H.M. 1970. Determination of the first-limiting amino acid of wheat and triticale grain for humans. Cereal Chem. 47, 615-622.

Leth, T. and Sondergaro, H. 1983. Biological activity of all- trance tocopherol determined by three different rat bioassays. Int. J. Vit. Nutr. Res. 53, 297-311.

Mendoza, C. 2002. Effect of genetically modified low phytic acid plants on mineral absorption. Int. J. Food Sci. Technol., 37, 759-767.

Moongngarm, A. and Saetung, N. 2010. Comparison of chemical composition and bioactive compounds of germinated rough rice and brown rice. Food Chem. 122, 782-788.

Morad, M.M., Leung, H.K., Hsu, D.L. and Finney, P.L. 1980. Effect of germination on physicochemical and bread-baking properties of yellow pea, lentil, and faba bean flours and starches. Cereal Chem. 57, 390 - 396.

Mune-Mune M.A., Minka, S.R., Mbome, I.L. and Etoba, F.X. 2011. Nutrition potential of Bambara been protein concentrate. Pakistan J. Nutr. 10(2), 112-119.

Nwabueze, T.U. 2007. Nitrogen solubility index and amino acid profile of extruded African breadfruit (T. Africana) blends. Nig. Food J. $25,35-35$.

Oates, L., Cohen, M., Braun, L., Schembri, A., Taskova, R. 2014. Reduction in urinary organophosphate pesticide metabolites in adults after a week-long organic diet. Environ. Res. 132, 105-111.

Okoye Z.S.C. 1992. Biochemical Aspects of Nutrition Prentice-Hall of India, New Delhi, India. pp. 147-105.

Oser, B.L. 1959. An integrated essential amino acid index for predicting the biological value of proteins.In protein and amino acid nutrition, (ed. A.A. Albanese).Academic Press, New York, USA. pp. 295-311.

Oyarekua, M.A. and Eleyinmi, A.F. 2004. Comparative evaluation of the nutritional quality of corn, sorghum and millet ogi prepared by modified traditional technique. Food Agric. Environ. 2, 94-99.

Pallanca, J.E. and Smirnoff, N. 1999. Ascorbic acid metabolism in pea seedlings. A comparison of D- Glucosone, L-Sorbosone and LGalactono-1,4-Lacton as ascorbate precursors. Plant Physiol. 120(2), 453 - 462.

Paraskevopoulou, A., Provatidou, E., Tsotsiou D.D. and Kiosseoglou, V. 2010. Dough rheology and baking performance of wheat flour- lupin protein isolate blends. Food Res. Int. 43, 1009-1016.

Pèrez-Balibrea, S., Moreno, D. and GarciaViguera, C. 2008. Influence of light on healthpromoting phytochemicals of broccoli sprouts. J. Sci. Food Agri. 88, 904 - 910.

Pollard, N.J., Stoddard, F.L., Popineau, Y., Wrigley, C.W. and MacRitchie, F. 2002. Lupin Flours as Additives: Dough Mixing, Breadmaking, Emulsifying, and Foaming. Cereal Chem. 79, 662-669.

Pomeranz, Y., Shogren, H.D. and Finney, K.F. 1977. Flour from germinated soybean in highprotein bread. J. Food Sci. 42, 824 - 827.

Premakumari, S., Balasasirekha, R., Gomathi, K., Supriya, S., Jaganmohan, R. and Alagsundram, K. 2012. Development and acceptability of fiber enriched ready mixes. International J. of Pure Appl. Sci. Technol. 9(2), 74-83.

Roohinejad, S., Mirhosseini, H., Saari, N., Mustafa, S., Alias, I. and Hussi, A.S.M. 2009. Evaluation of GABA, crude protein and amino acid composition from different varieties of Malaysian's brown rice. Australian J. Crops Sci. 3(4), 184-190.

Saha, R. and Dunkwal, V. 2009. Developmant and nutritional analysis of value added spread instant mix. J. Human Ecol. 28(3), 187-190.

Sandstrom, B., Almgren, A., Kivisto, B. and Cederblad, A. 1989. Effect of protein and protein source on zinc absorption in humans. J. Nutr., 119, 48-53.

Santos, J., Herrero, M., Mendiola, J.A., OlivaTeles, M.T., Ibannez, E., Delerue-Matos, C. and Oliveira, M.B.P.P. 2014. Assessment of nutritional and metabolic profiles of pea shoots: The new read - to - eat baby - leaf vegetable. Food Res. Int., 58, 105-111.

Schulze, H., Savelkoul, F.H.M.G., Verstegen, M.W., Van der Poel, A.F.B., Tamminga, S. and Groot Nibbelin, S. 1997. Nutritional evaluation of biologically treated white kidney beans ( Phoseolus vulgaris L.) in pigs: ileal and amino acid digestibility. J. Animal Sci, 75, 3187- 3194.

Shah, S.A., Zeb, A., Masood, T., Noreen, N., Abbas, S.J., Samiullah, M., Abdul Alim, M. and Muhammed, A. 2011. Effects of sprouting time on biochemical and nutritional qualities of mung bean varieties. African J. of Agric. Res. 6(22), 5091- 5098. 
Shu, X.L., Frank, T., Shu, Q.Y. and Engel, K.R. 2008. Metabolite profiling of germination rice seeds. J. Agric. Food Chem. 56(24), 1161211620.

Snedecor, G.W. and Cochran, W.G. 1980. Statistical methods $7^{\text {th }}$ ed., lowa State Univ. Press, Ames lowa, USA, Hard Cover: 507 p.

Sudha, M.L.R., Vertimani, K. and Leelavathi, K. 2007. Influence of fiber from different cereals on the rheological characteristics of wheat flour dough and on biscuit quality. Food Chem. 100, 1365-1370.
Tiwari, N. and Awasthi, P. 2014. Effect of different processing techniques on nutritional characteristics of oat (Avena saiva) grains and formulated weaning mixes. J. Food Sci. Technol. 51(9), 2256 - 2259.

Xu, Z.M.N. and Godber, J.S. 2001.Antioxidant activity of tocopherols and gamma oryzanol components from rice bran against cholesterol oxidation accelerated by 2,2-azobis (2methylpropionamidine) dihydrochloride. J. Agric. Food Chem., 49(4), 2077-2081. 